\title{
Management of sigmoid perforation from chronic constipation and manual disimpaction
}

\author{
Derek Lim, Shinban Liu, George Ferzli
}

General Surgery, NYU Langone Medical Center, Brooklyn, New York, USA

\section{Correspondence to}

Dr Shinban Liu,

shinban.liu@nyumc.org

DL and SL contributed equally.

Accepted 3 August 2018

\section{Check for updates}

(c) BMJ Publishing Group Limited 2018. No commercial re-use. See rights and permissions. Published by BMJ.

\begin{tabular}{|l|}
\hline To cite: Lim D, Liu S, \\
Ferzli G. BMJ Case Rep \\
Published Online First: \\
[please include Day Month \\
Year]. doi:10.1136/bcr-2018- \\
226886 \\
\hline
\end{tabular}

\section{DESCRIPTION}

A 41-year-old man with medical history of paraplegia as the result of spinal surgery complications and chronic constipation secondary to chronic opioid use and neurogenic colon requiring frequent enemas and manual disimpaction presents to the emergency room with diffuse abdominal pain after digital disimpaction. On examination, his abdomen was tender, rigid and distended with general peritonitis. Laboratory values were significant for leucopaenia of $3.3 \mathrm{k} / \mu \mathrm{L}$ and elevated lactate of $2.25 \mathrm{mmol} / \mathrm{L}$. CT of the abdomen and pelvis demonstrated a perforated sigmoid colon with an $8.3 \mathrm{~cm}$ defect and peritoneal spillage of faecal contents with scattered foci of free air (figure 1). He was taken emergently for an exploratory laparotomy where the rectosigmoid colon perforation was identified, surrounding colon was resected and copious washout performed for the litre of faecal material in the peritoneum. The bowel was left in discontinuity, and an open abdomen negative pressure therapy vacuum was placed. The patient was resuscitated in the surgical intensive care unit and later returned to the operating room for a formal closure and colostomy creation. His remaining postoperative course was uncomplicated, and he was discharged to a rehabilitation facility.

Colonic perforation secondary to stercoral ulceration is rare. It was first reported in 1894 and contributes to only $3.2 \%$ of all colonic perforations. ${ }^{1}$ Our patient exhibited multiple major risk factors that promoted a stercoral ulcer formation and subsequent perforation. There is a prevalence rate of $17 \%$ in hospitalised patients who had a spinal cord injury to develop faecal impaction. ${ }^{2}$ His chronic opioid usage also predisposed him to develop constipation. Constipation is a very common debilitating disorder

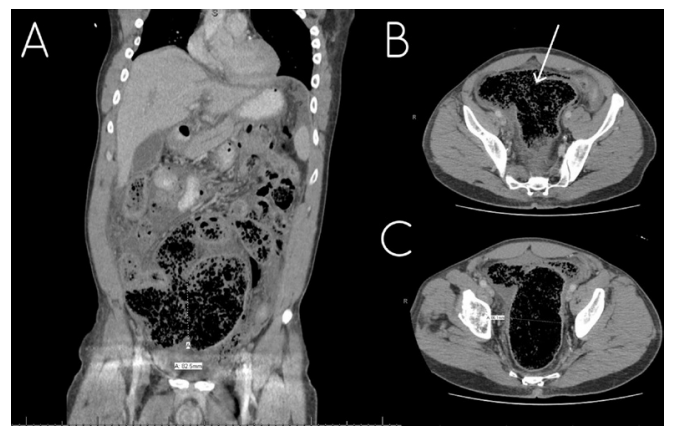

Figure 1 (A) Coronal $\mathrm{CT}$ of the abdomen and pelvis demonstrating large faecal load, free perforation and spillage of faecal material. (B) White arrow marking $8 \mathrm{~cm}$ right sigmoid defect. (C) Dilated rectum measuring $8.6 \mathrm{~cm}$. seen in the hospital. The prevalence of this disorder ranges depending on age and population; however the elderly is most at risk. Factors that predispose patients to constipation include lifestyle (dehydration, immobility and low fibre), anatomic (stricture, anal fissure and extrinsic mass), neurological (spinal cord injury, Parkinson's disease, dementia and Hirschsprung's disease), metabolic (hypothyroidism, hypocalcaemia and hypokalaemia) or medication induced (opioids and antipsychotics). Chronic constipation can lead to faecal impaction, stercoral ulcer formation and perforation, which can be life threatening with an associated mortality rate of $47 \% .^{3}$ Faecal impaction can be defined as symptoms of constipation in the presence of an obstructing faecal mass diagnosed on imaging or digital rectal exam. Prompt treatment is essential requiring disimpaction (manual or endoscopic), evacuation of the colon (enemas and polyethylene glycol) and maintenance bowel regimen to prevent recurrence. If left untreated, a stercoral ulcer may form, which is a result of prolonged pressure ischaemia of the faecaloma on the surrounding colonic mucosa that can lead to weakening and perforation.

\section{Learning points}

- Factors such as spinal cord injury and opioid use can result in chronic constipation and faecal impaction.

- Stercoral ulcers may form secondary to prolonged pressure ischaemia that can lead to perforation.

- Bowel perforation requires emergent operative management, which may include exploratory laparotomy, bowel resection and ostomy formation.

Contributors All authors contributed equally to the treatment of this patient, drafting and editing of this manuscript, and submission.

Funding The authors have not declared a specific grant for this research from any funding agency in the public, commercial or not-for-profit sectors.

Competing interests None declared.

Patient consent Obtained.

Provenance and peer review Not commissioned; externally peer reviewed.

\section{REFERENCES}

1 Oakenful C, Lambrianides AL. Stercoral perforation of the rectum. Emerg Med Australas 2011;23:224-7.

2 Hussain ZH, Whitehead DA, Lacy BE. Fecal impaction. Curr Gastroenterol Rep 2014;16:404.

3 Kanwal D, Attia KME, Fam MNA, et al. Stercoral perforation of the rectum with faecal peritonitis and pneumatosis coli: A case Report. J Radiol Case Rep 2017;11:1-6. 
Copyright 2018 BMJ Publishing Group. All rights reserved. For permission to reuse any of this content visit http://group.bmj.com/group/rights-licensing/permissions.

BMJ Case Report Fellows may re-use this article for personal use and teaching without any further permission.

Become a Fellow of BMJ Case Reports today and you can:

- Submit as many cases as you like

- Enjoy fast sympathetic peer review and rapid publication of accepted articles

Access all the published articles

- Re-use any of the published material for personal use and teaching without further permission

For information on Institutional Fellowships contact consortiasales@bmjgroup.com

Visit casereports.bmj.com for more articles like this and to become a Fellow 